\title{
Chromosome numbers in some alien plant species of Novosibirsk Region: post II
}

\author{
E. Yu. Zykova ${ }^{1,2 *}$, T. V. Pankova (An'kova) ${ }^{1,3}$ \\ ${ }^{I}$ Federal State Institution of Science Central Siberian Botanical Garden of Siberian Branch of RAS, \\ Zolotodolinskaya str., 101, Novosibirsk, 630090, Russian Federation \\ ${ }^{2}$ E-mail: elena.yu.zykova@gmail.com; ORCID iD: https://orcid.org/0000-0002-1847-5835 \\ ${ }^{3}$ ORCID iD: https://orcid.org/0000-0003-3661-0719 \\ * Corresponding author
}

Keywords: diploid, invasive species, Novosibirsk Region, polyploid.

Summary. Chromosome numbers (2n) for 12 alien species (Apiaceae, Asteraceae, Brassicaceae, Campanulaceae, Fabaceae, Lamiaceae, Malvaceae, Onagraceae, Poaceae, Polygonaceae) from the Novosibirsk Region are given. For the first time for Russia, the number of chromosomes of Xanthogalum purpurascens $(2 n=22)$ is given, for Siberia Nepeta cataria $(2 n=34)$, Malva pusilla $(2 n=42)$ and Koenigia weyrichii subsp. weyrichii $(2 n=20)$. For all studied species, short information on the general distribution and dispersal in the Novosibirsk Region, literature data on the number of chromosomes from the territory of Russia are presented.

\section{Числа хромосом некоторых чужеземных видов растений Новосибирской области: сообщение 2}

\author{
Е. Ю. Зыкова, Т. В. Панкова (Анькова) \\ Федеральное государственное бюджетное учреждение науки «Центральный сибирский ботанический сад» \\ Сибирского отделения РАН, ул. Золотодолинская, 101, г. Новосибирск, 630090, Россия
}

Ключевые слова: диплоид, инвазивные виды, Новосибирская область, полиплоид.

Аннотация. Приводятся числа хромосом (2n) для 12 адвентивных видов семейств Apiaceae, Asteraceae, Brassicaceae, Campanulaceae, Fabaceae, Lamiaceae, Malvaceae, Onagraceae, Poaceae, Polygonaceae из Новосибирской области. Впервые для России приводится число хромосом Xanthogalum purpurascens $(2 n=22)$, для Сибири - Nepeta cataria $(2 n=34)$, Malva pusilla $(2 n=42)$ и Koenigia weyrichii subsp. weyrichii $(2 n=20)$. Для всех исследованных видов приводятся краткие сведения по общему распространению и расселению в Новосибирской области, литературные данные по числам хромосом с территории России.

We continue the karyological study of invasive and potentially invasive species in the flora of the Novosibirsk Region (An'kova, Zykova, 2020, 2021). The article presents the results of studying 12 species found in the Novosibirsk Region. These are widespread in the area: Brassica rapa subsp. oleifera, Vicia hirsuta, Elsholtzia ciliata, Malva pusilla and Echinochloa crus-galli; very active in newly discovered habitats: Xanthogalum purpurascens, Campanula rapunculoides, Epilobium pseudorubescens and Koenigia weyrichii; rarely found in most areas of the region: 
Galeopsis ladanum and recently discovered and rare in the city of Novosibirsk: Senecio viscosus and Nepeta cataria. The chromosome numbers were determined by direct counting in metaphase on root meristem squash preparations. Seeds were germinated on sterile sand. The root tips were pretreated for two hours with $0.2 \%$ colchicine water solution, fixed in $3: 1$ absolute ethanol glacial acetic acid and stained with $1 \%$ acetic hematoxylin. Metaphase plates were observed under $100 \times$ magnification by the Axioscope 40 (Karl Zeiss, Axio Lab) and photographed by the AxiCam MRc 5 digital camera.

For all species, the references on chromosome numbers revealed from the samples collected in Russia are given as well, as relevant information in the international database "The Chromosome Counts Database" (Rice et al., 2015) is reflected incompletely. Latin names of plants are given according to the "Catalog of Life" (Hassler, 2020). The herbarium samples will be transferred at the Herbarium of the Central Siberian Botanical Garden of Siberian Branch of the Russian Academy Sciences (NS, Novosibirsk).

\section{APIACEAE}

Xanthogalum purpurascens Avé-Lall. (Angelica purpurascens (Ave-Lall.) Gilli), $2 \boldsymbol{n}=\mathbf{2 2}$

"Novosibirsk Region, Novosibirsk city, Akademgorodok, territory of the Central Siberian Botanical Garden, old overgrown sites. 8 IX 2018. E. Zykova", 3718-Z684 (Fig. 1A).

Distribution: native to Caucasus, Turkey and Iran. Species is cultivated in botanical gardens, goes wild. It is preserved on the old fallows of the Central Siberian Botanical Garden, actively spreads in the nearby forests (Zykova, Shaulo, 2019).

The chromosome number was determined in Russia for the first time. The same chromosome number was reported for the Georgia (Vasilyeva et al., 1981; Vasilyeva, Pimenov, 1991), the Turkey (Pimenov et al., 1998).

Diploid $(2 x), x=11$.

\section{ASTERACEAE}

Senecio viscosus $\mathrm{L}$., $2 n=40$

"Novosibirsk Region, Novosibirsk city, Soviet microdistrict, surroundings of the "Seyatel" station, in the yards, outside the flower beds. 30 VIII 2019. E. Zykova”, 1119-Z767.

Distribution: S. viscosus is native Western and Central Europe, and the Caucasus. The location of the species has been recorded since the 1980s in
Siberia. For the Novosibirsk Region, it was recorded for the first time in 2019 (Ebel, Zykova, 2021).

The chromosome number is given for Western Siberia for the first time. The same chromosome number was determined for the Irkutsk Region (Chepinoga, 2014, and references therein) and the Primorye Territory (Probatova, 2014, and references therein); $2 n=20$ was defined for the Primorye Territory (Probatova, 2014, and references therein).

Tetraploid $(4 x), x=10$.

\section{BRASSICACEAE \\ Brassica rapa subsp. oleifera (DC.) Metzg.} (B. campestris L.), $\mathbf{2} \boldsymbol{n}=\mathbf{2 0}$

"Novosibirsk Region, Novosibirsk city, Soviet microdistrict, Kirov village, wasteland. 19 IX 2017. E. Zykova, T. Shemetova”, 7417-Z372.

Distribution: Eurasian species, common in all regions of Siberia. At the beginning of the 20th century the species was known in most of the Tomsk province (which included the Novosibirsk Region) in the fields, near houses and roads, sometimes in meadows (Krylov, 1901). To date, it has been registered in 18 districts of the region (Zykova, 2019).

The same number of chromosomes was counted for the Novosibirsk Academgorodok (Krasnikov, Lomonosova, 1990), the Irkutsk Region (Chepinoga, 2014, and references therein) and the Primorye Territory (Probatova, 2014, and references therein).

Diploid $(2 x), x=10$.

\section{CAMPANULACEAE}

\section{Campanula rapunculoides L., $2 n=102$}

"Novosibirsk Region, Novosibirsk city, Akademgorodok, territory of the Central Siberian Botanical Garden, old overgrown sites. 15 IX 2018. E. Zykova", 4018-Z777, 4018-Z778.

Distribution: native to Europe and North Africa. It is widely cultivated as an ornamental plant, including in Siberia, and often goes wild. In the Novosibirsk Region, it was noted to become naturalized in 2014 (Zykova et al., 2014); it is abundant in the discovered habitats (Zykova, 2019).

For the Novosibirsk Region, the chromosome number is given for the first time. $2 n=102$ was also determined for the Tomsk Region (Malakhova, 1990); $2 n=68$ was counted for the Irkutsk Region (Chepinoga, 2014, and references therein). The number $2 n=102$ may have arisen by chromosome doubling of a triploid: 3 X $17 \rightarrow 51$; 2 X $51 \rightarrow 102$ (Gadella, 1964).

Hexaploid (6x), $x=17$. 


\section{FABACEAE}

Vicia hirsuta (L.) Gray, $2 n=14$

"Novosibirsk Region, Novosibirsk city, Akademgorodok, territory of the Central Siberian Botanical Garden, Bonsai Park, weed along the paths. 24 VII 2012. E. Korolyuk, E. Zykova”, 1812Z522 (Fig. 1B).

Distribution: the European-Mediterranean species, which has spread throughout the globe. It is one of the active invasive species in Siberia (Ebel et al., 2014). Species was introduced to the Novosibirsk Region in the 1960s (Krylov, Sergievskaya, 1964), it is known in ten districts of the region (Zykova, 2019).

The chromosome number is given for the Novosibirsk Region for the first time. The same chromosome number was counted from the Irkutsk Region (Chepinoga, 2014, and references therein), the Primorye Territory (Probatova, 2014, and references therein), the Khabarovsk Territory (Probatova et al., 2011), the Republic of Ingushetia (Efimov, 1987), and the Republic of Altai (Zykova et al., 2020).

Diploid $(2 x), x=7$.

\section{LAMIACEAE}

Elsholtzia ciliata (Thunb.) Hyl., $2 \boldsymbol{n}=\mathbf{1 6}$

"Novosibirsk Region, Novosibirsk city, Soviet microdistrict, Geroev Truda street, in yards $54^{\circ} 51^{\prime} 37.73^{\prime \prime} \mathrm{N}, \quad 83^{\circ} 04^{\prime} 45.54^{\prime \prime}$ E. 10 IX 2018. T. An'kova", Z650.

Distribution: the East-Asian species that has spread to Europe and North America. It belongs to the invasive plants in Central Russia (Vinogradova et al., 2010) and Siberia (Ebel et al., 2014). In the Novosibirsk Region, it is noted as common in all inhabited districts (Shaulo, 2000), however, specimens in herbarium are only from the Novosibirsk city (Zykova, 2019).

The chromosome number is given for the Novosibirsk Region for the first time. The same number was determined for the Krasnoyarsk Territory (Stepanov, 1994), the Irkutsk Region (Chepinoga, 2014, and references therein), the Primorye Territory (Probatova, 2014, and references therein) and the Amur Region (Probatova et al., 2006).

Diploid $(2 x), x=8$.

\section{Galeopsis ladanum L., $2 n=16$}

"Novosibirsk Region, Novosibirsk city, Soviet microdistrict, Zolotodolinskaya street, in yards, on lawns. 20 IX 2019. E. Zykova", 2219-Z813.

Distribution: the eurasian species, rare in the regions of Siberia. Since the 1930s it has been known in the Novosibirsk Region (Krylov, 1937), now it is rarely found in most areas of the region (Zykova, 2019).

The chromosome number for the Novosibirsk Region is given for the first time. The same number was determined for the Krasnoyarsk Territory (Stepanov, Muratova, 1995) and the Irkutsk Region (Probatova et al., 2018).

Diploid $(2 x), x=8$.

\section{Nepeta cataria L., $2 n=34$}

"Novosibirsk Region, Novosibirsk district, dacha society "Flora-1", along the tracks. 31 VIII 2019. E. Zykova", 1419-Z766.

Distribution: the native species to Europe, the Caucasus, Western and Central Asia, introduced to the Far East and North America. It is grown as a spice and medical plant in most regions of Western Siberia, occasionally becomes wild. It was first recorded in the Novosibirsk Region in 2010 from Novosibirsk city (Zykova, 2015); by now, it is extremely rare here (Zykova, 2019).

The chromosome number was determined on the Siberian material for the first time. The number $2 n=$ 34 and $2 n=36$ was revealed for the Primorye Territory (Probatova, 2014, and references therein).

Diploid $(2 x), x=17$.

\section{MALVACEAE}

Malva pusilla $\mathrm{Sm} ., 2 n=42$

"Novosibirsk Region, Novosibirsk city, Central microdistrict, Serebrennikovskaya street, in overgrown flower beds. 19 IX 2019. E. Zykova", 1919Z807.

Distribution: Holarctic species. In Siberia, including the Novosibirsk Region, it is a widespread ruderal weed.

The chromosome number was determined on the Siberian material for the first time. The same number was determined for the Primorye Territory (Probatova, 2014, and references therein).

Hexaploid (6x), $x=7$.

\section{ONAGRACEAE}

Epilobium pseudorubescens A. K. Skvortsov, $2 n=36$

"Novosibirsk Region, Novosibirsk city, Akademgorodok, Morskoy prospect, in the courtyards. 05 IX 2018. E. Zykova", 3418-Z814; "Novosibirsk Region, Novosibirsk city, Akademgorodok, Nikolaev street, wasteland. 07 IX 2018. E. Zykova", 3618-Z815.

Distribution: North American species spreading throughout the Holarctic. In the European part of Russia, it is one of the most aggressive invasive 
species (Vinogradova et al., 2010). It spreads actively across Siberia (Ebel, 2013; Buko, 2016). In the Novosibirsk Region, it was found in the Ust-Tarksk district (Ebel, 2008) and in the city of Novosibirsk (Zykova, 2015).

The chromosome number is given from the Novosibirsk Region for the first time. The same number was determined for the Tomsk Region (Probatova et al., 2016).

Tetraploid (4x), $x=9$.

\section{POACEAE}

Echinochloa crus-galli (L.) P. Beauv., $2 n=54$

"Novosibirsk Region, Novosibirsk city, Soviet microdistrict, Akademgorodok, Nikolaev street, by the roads. 01 VIII 2017. E. Zykova", 3917-Z379 (Fig. 1C).

Distribution: the South Asian species with a cosmopolitan secondary range that has settled in the regions of Southern Siberia. It is included in the list of invasive and potentially invasive species of Siberia (Ebel et al., 2014) and the Black Book of Siberian Flora (Sheremetova, 2016). The species has been noted since the early 20th century in the Novosibirsk Region (Krylov, 1928), now it is quite common here.

The chromosome number is given for the Novosibirsk Region for the first time. The same one was
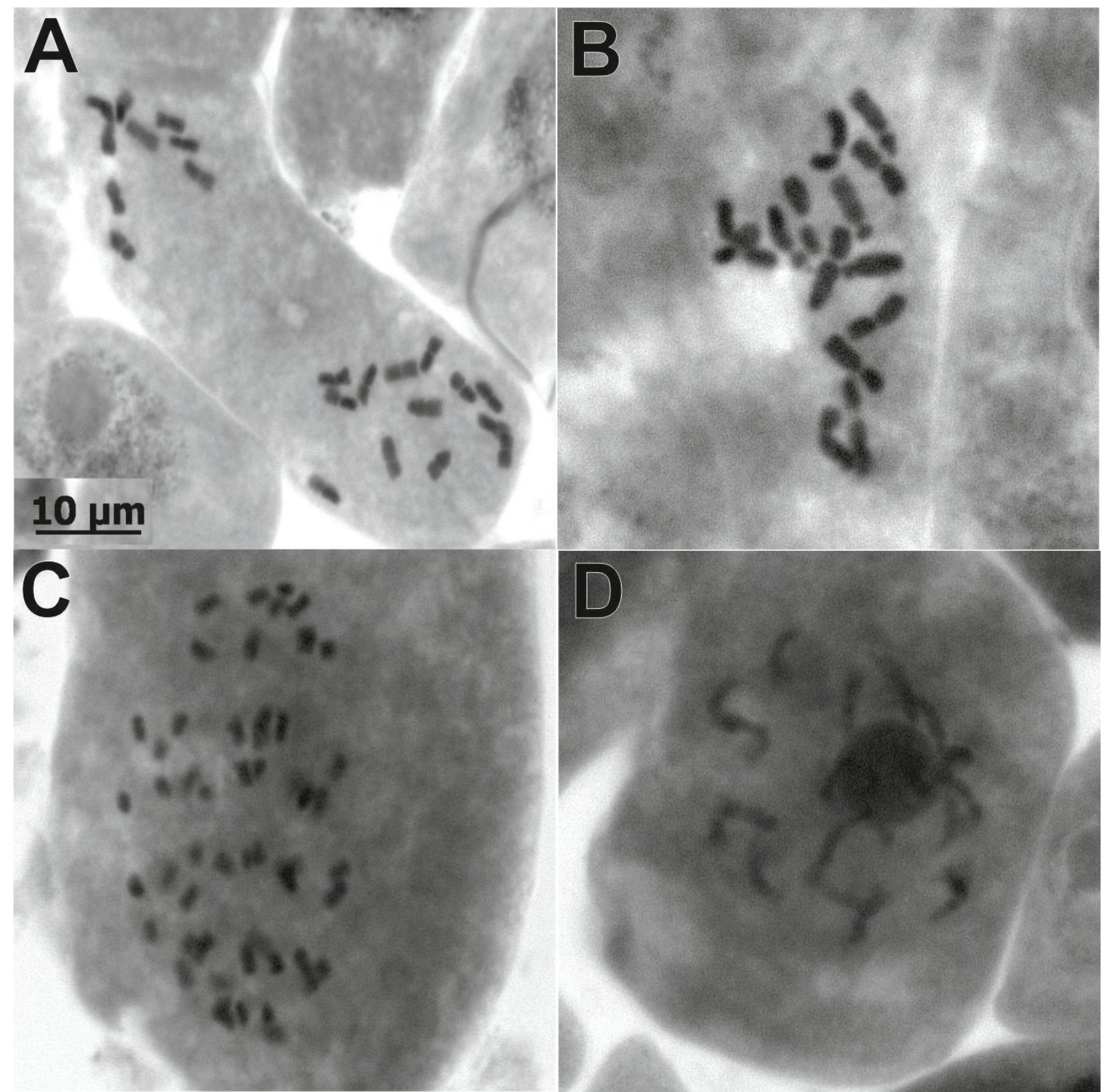

Fig. 1. Mitotic metaphases: A - Xanthogalum purpurascens, $2 n=22 ; \mathbf{B}-$ Vicia hirsuta, $2 n=14 ; \mathbf{C}-$ Echinochloa crus-galli, $2 n=54$; D - Koenigia weyrichii subsp. weyrichii, $2 n=20$. 
counted for the Irkutsk Region (Chepinoga, 2014, and references therein), the Amur Region (Probatova, Sokolovskaya, 1983), the Primorye Territory (Probatova, 2014, and references therein) and the Kamchatka Territory (Probatova et al., 2017). Tetraploid level $(2 n=36)$ was determined for the Krasnoyarsk Territory (Stepanov, Muratova, 1992).

Hexaploid $(6 x), x=9$.

\section{POLYGONACEAE}

Koenigia weyrichii (F. Schmidt) T. M. Schust. et Reveal subsp. weyrichii (Polygonum weyrichii F. Schmidt), $\mathbf{2} \boldsymbol{n}=\mathbf{2 0}$

"Novosibirsk Region, Novosibirsk district, Akademgorodok, mixed forest across the road from the old exhibition areas of the Central Siberian Botanical Garden. 02 X 2019. E. Zykova”, 2319-Z812 (Fig. 1D).

Distribution: the far-eastern species grows on Sakhalin, the Kuril Islands, Japan, China. Species was growing as an ornamental plant, remains in old fallow expositions of the Central Siberian Botanical Garden, actively spreads in ravines and forests, forming extensive thickets in glades (Zykova, 2019).
The chromosome number on the Siberian material was determined for the first time. The same number was determined from the Sakhalin Region (Probatova et al., 2007).

Diploid $(2 x), x=10$.

\section{Conclusion}

The chromosome numbers of 12 alien species from West Siberian populations (except for Brassica rapa subsp. oleifera) were studied for the first time. Seven species are diploids with high basic numbers $(x=7,8,10,11,17)$, five are polyploids (tetraploids Senecio viscosus, Epilobium pseudorubescens, hexaploids Campanula rapunculoides, Malva pusilla and Echinochloa crus-galli). Our data on ploidy level of the species from West Siberian populations is compared with those literature data on the populations of Eastern Siberia and the Far East.

\section{Acknowledgements}

The study was carried out in the framework of the scientific program of the Central Siberian Botanical Garden SB RAS (AAAA-A21-121011290024-5).

\section{REFERENCES / ЛИТЕРАТУРА}

An'kova T. V., Zykova E. Yu. 2020. Chromosome numbers in some alien plant species of Novosibirsk Region (Novosibirsk city): post I. Turczaninowia 23, 3: 5-11. DOI: 10.14258/turczaninowia.23.3.1

An'kova T. V., Zykova E. Yu. 2021. Alien species in the Novosibirsk City, Russia. In: Botanica Pacifica plant chromosome data 1 (N. S. Probatova, ed.). Botanica Pacifica 10(1): 110. DOI: 10.17581/bp.2021.10103

Buko T. E. 2016. Epilobium pseudorubescens A. Skvortsov. In: Chyernaya kniga flory Sibiri [Black book of the flora of Siberia]. Novosibirsk: “Geo" Publ. Pp. 288-291. [In Russian] (Буко T. E. Epilobium pseudorubescens A. Skvortsov // Черная книга флоры Сибири. Новосибирск: Академическое изд-во «Гео», 2016. С. 288-291).

Chepinoga V. V. 2014. Chromosome numbers of plant species from Baikal Siberia. Novosibirsk: Nauka. 419 pp. [In Russian] (Чепинога В. В. Хромосомные числа растений флоры Байкальской Сибири. Новосибирск: Наука, 2014. 419 c.).

Ebel A. L. 2008. New and rare species of flowering plants to the flora of Altai mountain country. Turczaninowia 11, 4: 77-85. [In Russian] (Эбель A. Л. Новые и редкие виды цветковых растений для флоры Алтайской горной страны // Turczaninowia, 2008. T. 11, № 4. C. 77-85). URL: http://old.ssbg.asu.ru/turcz/turcz4_08_77_85.pdf

Ebel A. L. 2013. On the distribution of Epilobium pseudorubescens (Onagraceae) in Siberia. Turczaninowia 16, 3: 112-115. [In Russian] (Эбель A. Л. О распространении Epilobium pseudorubescens (Onagraceae) в Сибири // Turczaninowia, 2013. T. 16, № 3. C. 112-115). DOI: 10.14258/turczaninowia.16.3.18

Ebel A. L., Strelnikova T. O., Kupriyanov A. N., Anenkhonov O. A., Ankipovich E. C., Antipova E. M., Verkhozina A. V., Efremov A. N., Zykova E. Yu., Mikhailova S. I., Plikina N. V., Ryabovol S. V., Silantieva M. M., Stepanov N. V., Terekhina T. A., Chernova O. D., Shaulo D. N. 2014. Invasive and potential invasive species of Siberia. Byull. Glavn. bot. sada (Moscow) [Bulletin Main Botanical Garden] 1(200): 52-61. [In Russian] (Эбель А. Л., Стрельникова Т. О., Куприянов А. Н., Аненхонов О. А., Анкипович Е. С., Антипова Е. М., Верхозина А. В., Ефремов А. Н., Зыкова Е. Ю., Михайлова С. И., Пликина Н. В., Рябовол С. В., Силантвева М. М., Степанов Н. В., Терехина Т. А., Чернова О. Д., Шауло Д. Н. Инвазионные и потенциально инвазионные виды Сибири // Бюл. Глав. ботан. сада, 2014. № 1 (вып. 200). С. 52-61). URL: http://www.gbsad.ru/science/doc/ biulleten_gbs_2014_200_1.pdf

Ebel A. L., Zykova E. Yu. 2021. Senecio viscosus L. (Asteraceae). In: Findings to the flora of Russia and adjacent countries: New national and regional vascular plant records, 3 (A.V. Verkhozina, ed.). Botanica Pacifica 10(1): 96-97. DOI: $10.17581 / \mathrm{bp} .2021 .10110$ 
Efimov K. F. 1987. Chromosome numbers in some members of the Fabaceae from central Caucasus. Bot. Zhurn 72(6): 845. [In Russian] (Ефимов К. Ф. Числа хромосом некоторых видов семейства Fаbасеае Центрального Кавказа // Бот. журн., 1987. Т. 72, № 6. С. 845).

Gadella Th. W. J. 1964. Cytotaxonomic studies in the genus Campanula. Wentia 11: 1-104.

Hassler M. 2020. World Plants: Synonymic Checklists of the Vascular Plants of the World (version Nov 2018). In: Species 2000 \& ITIS Catalogue of Life, 2020-08-01 Beta. Y. Roskov, G. Ower, T. Orrell, D. Nicolson, N. Bailly, P. M. Kirk, T. Bourgoin, R. E. DeWalt, W. Decock, E. van Nieukerken, L. Penev (eds). Species 2000: Naturalis, Leiden, the Netherlands. URL: www.catalogueoflife.org/col (Accessed 11 April 2021).

Krasnikov A. A., Lomonosova M. N. 1990. Chromosome numbers in representatives of some families of vascular plants in the flora of the Novosibirsk Region. I. Bot. Zhurn. 75(1): 116-118. [In Russian] (Красников А. А., Ломоносова М. Н. Хромосомные числа представителей из некоторых семейств флоры Новосибирской области, $1 / /$ Бот. журн., 1990. Т. 75, № 1. С. 116-118).

Krylov P. N. 1901. Brassica L. In: Flora Altaya i Tomskoy gubernii [Flora of Altai and Tomsk province]. Vol. 1. Tomsk: Typo-lithograph by M. N. Kononov. Pp. 116-117. [In Russian] (Крылов П. Н. Brassica L. // Флора Алтая и Томской губернии. Т. 1. Томск: Типо-литография М. Н. Кононова, 1901. С. 116-117).

Krylov P. N. 1928. Panicum L. In: Flora Zapadnoy Sibiri [Flora of Western Siberia]. Vol. 2. Tomsk: "Krasnoye znamya" Publ. Pp. 149-151. [In Russian] (Крылов П. Н. Рапісит L. // Флора Западной Сибири. Т. 2. Томск: издво «Красное знамя», 1928. С. 149-151).

Krylov P. N. 1937. Galeopsis L. In: Flora Zapadnoy Sibiri [Flora of Western Siberia]. Vol. 9. Tomsk: "Krasnoye znamya" Publ. Pp. 2345-2349. [In Russian] (Крылов П. Н. Galeopsis L. // Флора Западной Сибири. Т. 9. Томск: изд-во «Красное знамя», 1937. С. 2345-2349).

Krylov P. N., Sergievskaya L. P. 1964. Vicia L. In: Flora Zapadnoy Sibiri [Flora of Western Siberia]. Vol. 12(2). Tomsk: Tomsk University Press. P. 3379. [In Russian] (Крыльв П. Н., Сергиевская Л. П. Vісіа L. // Флора Западной Сибири. Т. 12(2). Томск: Изд-во Томск. ун-та, 1964. С. 3379).

Malakhova L. A. 1990. Karyological analysis of natural populations of rare and endangered plants in the south of Tomsk Region. Byull. Glavn. bot. sada (Moscow) [Bulletin of the Main Botanical Garden] 155: 60-66. [In Russian] (Малахова Л. $\boldsymbol{A}$. Кариологический анализ природных популяций редких и исчезающих растений на юге Томской области // Бюл. Глав. ботан. сада, 1990. Вып. 155. С. 60-66). URL: http://www.gbsad.ru/science/doc/ biulleten_gbs_1990_155.pdf

Pimenov M. G., Alexeeva T. V., Kljuykov E. V. 1998. Mediterranean chromosome number reports - 8 (905-935). Flora Mediterranea 8: 221-245.

Probatova N. S. 2014. Chromosome numbers in vascular plants of the Primorskii Territory (Russian Far East). Vladivostok: Dalnauka. 343 pp. [In Russian] (Пробатова Н. С. Хромосомные числа сосудистых растений Приморского края. Владивосток: Дальнаука, 2014. 343 с.).

Probatova N. S., Barkalov V. Yu., Rudyka E. G. 2007. Caryology of the flora of Sakhalin and the Kurile Islands. Chromosome numbers, taxonomic and phytogeographical comments. Vladivostok: Dalnauka. 392 pp. [In Russian] (Пробатова Н. С., Баркалов В. Ю., Рудыка Э. Г. Кариология флоры Сахалина и Курильских островов. Числа хромосом, таксономические и фитогеографические комментарии. Владивосток: Дальнаука, 2007. 392 с.).

Probatova N. S., Barkalov V. Yu., Stepanov N. V. 2017. Chromosome numbers in some vascular plant species from Siberia and the Russian Far East. Botanica Pacifica 6(1): 51-55. DOI: 10.17581/bp.2017.06103

Probatova N. S., Kazanovsky S. G., Chernyagina O. A. 2018. Chromosome numbers in some vascular plant species from Russia: Komi Republic, Volga Region, Siberia and the Far East. Botanica Pacifica 7(2): 157-161. DOI: 10.17581/bp.2018.072010

Probatova N. S., Kazanovsky S. G., Rudyka E. G., Barkalov V. Yu., Seledets V. P., Nechaev V. A. 2011. IAPT/ IOPB chromosome data 12 in Marhold (Ed.). Taxon 60(6): 1790-1794.

Probatova N. S., Krivenko D. A., Ebel A. L. 2016. IAPT/IOPB chromosome data 22 in Marhold (Ed.). Taxon 65(5): 1204-1205. DOI: 10.12705/655.40

Probatova N. S., Rudyka E. G., Barkalov V. Yu., Nesterova I. A., Kudrin S. G., Chubar E. A. 2006. Chromosome numbers of vascular plants from nature reserves of the Primorsky Territory and the Amur River basin. Bot. Zhurn. 91(7): 1117-1134. [In Russian] (Пробатова Н. С., Рудыка Э. Г., Баркалов В. Ю., Нестерова И. А., Кудрин $\boldsymbol{C}$. $\boldsymbol{\Gamma}$., Чубарь $\boldsymbol{E}$. $\boldsymbol{A}$. Числа хромосом сосудистых растений из заповедников Приморского края и Приамурья // Бот. журн., 2006. Т. 97, № 7. С. 1117-1134).

Probatova N. S., Sokolovskaya A. P. 1983. Chromosome numbers in Adoxaceae, Chloranthaceae, Cupressaceae, Juncaceae, Poaceae. Bot. Zhurn. 68(12): 1683-1684. [In Russian] (Пробатова Н. С., Соколовская А. П. Хромосомные числа: Adoxaceae, Chloranthaceae, Cupressaceae, Juncaceae, Poaceae // Бот. журн., 1983. Т. 68, № 12. C. 1683-1684).

Rice A., Glick L., Abadi S., Einhorn M., Kopelman N., Salman-Minkov A., Mayzel J., Chay O., Mayrose I. 2015. The Chromosome Counts Database (CCDB) - a community resource of plant chromosome numbers. New Phytol. 206(1): 19-25. URL: http://ccdb.tau.ac.il (Accessed 01 April 2021). 
Shaulo D. N. 2000. Elsholtzia Willd. In: Opredelitel rasteniy Novosibirskoy oblasti [Key to plants of Novosibirsk Region]. Novosibirsk: Nauka. P. 310. [In Russian] (Шауло Д. Н. Elsholtzia Willd. // Определитель растений Новосибирской области. Новосибирск: Наука, 2000. С. 310).

Sheremetova S. A. 2016. Echinochloa crusgalli (L.) Beauv. In: Chyernaya kniga flory Sibiri [Black book of the flora of Siberia]. Novosibirsk: "Geo" Publ. Pp. 302-308. [In Russian] (Шереметова C. A. Echinochloa crusgalli (L.) Beauv. // Черная книга флоры Сибири. Новосибирск: Академическое изд-во «Гео», 2016. C. 302-308).

Stepanov N. V. 1994. Chromosome numbers of some higher plants taxa of the flora of Krasnoyarsk Region. Bot. Zhurn. 79(2): 135-139. [In Russian] (Степанов Н. B. Числа хромосом некоторых таксонов высших растений флоры Красноярского края // Бот. журн., 1994. Т. 79, № 2. С. 135-139).

Stepanov N. V., Muratova E. N. 1992. Chromosome numbers of some species of higher plants of flora of the Krasnoyarsk Region. Bot. Zhurn. 77(7): 125-126. [In Russian] (Степанов Н. В., Муратова Е. Н. Числа хромосом некоторых видов высших растений флоры Красноярского края // Бот. журн., 1992. Т. 77, № 7. С. 125-126).

Stepanov N. V., Muratova E. N. 1995. Chromosome numbers of some taxa of higher plants of Krasnoyarsk territory. Bot. Zhurn. 80(6): 114-116. [In Russian] (Cтепанов H. B., Муратова E. H. Хромосомные числа некоторых таксонов высших растений Красноярского края // Бот. журн., 1995. Т. 80, № 6. С. 114-116).

Vasilyeva M. G., Pimenov M. G. 1991. Karyotaxonomical analysis in the genus Angelica (Umbelliferae). Pl. Syst. Evol. 177: 117-138. DOI: 10.1007/BF00937950

Vasilyeva M. G., Retina T. A., Pimenov M. G. 1981. Chromosomal figures of some Umbelliferae of the Caucasus and the south of the european part of the USSR. Biol. Nauki (Moscow) 207, 3: 60-65. [In Russian] (Васильева М. Г., Ретина T. А., Пименов М. Г. Хромосомные фигуры некоторых зонтичных Кавказа и юга европейской части СССР // Биологические науки, 1981. Т. 207, № 3. С. 60-65).

Vinogradova Yu. K., Majorov S. R., Horun L. V. 2010. Chernaya kniga flory Sredney Rossii (Chuzherodnyye vidy $v$ ekosistemakh Sredney Rossii) [The Black Book of flora of Central Russia (Alien species in ecosystems of Central Russia)]. Moscow: Geos. 505 pp. [In Russian] (Виноградова Ю. К., Майоров С. Р., Хорун Л. В. Черная книга флоры Средней России (Чужеродные виды растений в экосистемах Средней России). М.: Геос, 2010. 505 с.).

Zykova E. Yu. 2015. New and rare adventive species in the Novosibirsk Oblast, Altai Krai and Altai Republic. Rastitelnyy mir Aziatskoy Rossii [Plant Life of Asian Russia] 2(18): 68-71. [In Russian] (3ыкова Е. Ю. Новые и редкие виды адвентивных растений во флоре Новосибирской области, Алтайского края и Республики Алтай // Растительный мир Азиатской России, 2015. № 2(18). С. 68-71).

Zykova E. Yu. 2019. Alien flora of the Novosibirsk Region. Acta Biologica Sibirica 5, 4: 127-140. [In Russian] (Зыкова Е. Ю. Адвентивная флора Новосибирской области // Acta Biologica Sibirica, 2019. Вып. 5, № 4. С. 127-140). DOI: 10.14258/abs.v5.i4.7147

Zykova E. Yu., An'kova T. V., Lomonosova M. N. 2020. Chromosome numbers of invasive and potentially invasive species in the flora of the Republic of Altai. III. Turczaninowia 23, 1: 133-139. DOI: 10.14258/turczaninowia.23.1.15

Zykova E. Yu., Korolyuk A. Yu, Korolyuk E. A., Lashchinskiy N. N. 2014. High vascular plants. In: Rastitelnoye mnogoobraziye Tsentralnogo sibirskogo botanicheskogo sada SO RAN [Plant diversity of the Central Siberian botanical garden SB RAS]. Novosibirsk: "GEO" Publ. Pp. 318-437. [In Russian] (Зыкова Е. Ю., Королюк А. Ю., Королюк $\boldsymbol{E}$. А., Лащинский $\boldsymbol{H}$. Н. Высшие сосудистые растения // Растительное многообразие Центрального сибирского ботанического сада СО РАН. Новосибирск: Академическое изд-во «Гео», 2014. С. 318-437).

Zykova E. Yu., Shaulo D. N. 2019. Finds in the adventive flora of Novosibirsk Oblast. Turczaninowia 22, 3: 110-115. [In Russian] (Зыкова Е. Ю., Шауло Д. Н. Новинки в адвентивной флоре Новосибирской области // Turczaninowia, 2019. T. 22, № 3. C. 110-115. DOI: 10.14258/turczaninowia.22.3.6 